\title{
Simultaneous Recordings of Intraluminal \\ Pressure in Oviduct, Uterus and Cervix \\ in the Estrous Rabbit
}

\author{
Hiroyuki Suzuki, Yoshio Tsursumi and Keikitsu Ogawa* \\ Department of Animal Science, Faculty of Agriculture, Hokkaido \\ University, Sapporo-shi 060 \\ *Transducer Division, Nihon Kohden Kogyo Co. Ltd., \\ Shinjuku-ku 161
}

(Received November 17, 1980)

\begin{abstract}
Intraluminal pressures were simultaneously monitored in the ipsilateral oviduct, uterus and cervix of pre-ovulatory rabbits using a new type of polyurethane balloon catheter which was sealed with a nylon plug. Daily recordings were made in 19 rabbits for 15 to 32 days. Contractions of the oviduct were characterized by higher frequency ( $6.0 \pm$ $1.0 / \mathrm{min})$ than those of the uterus $(1.0 \pm 0.2 / \mathrm{min})$ and cervix $(1.9 \pm 0.5 / \mathrm{min})$. Outbursts of activity were repeatedly observed, but they did not always occur synchronously in these three different portions of the reproductive tract. There were daily variations in the activity in each organ. The highest amplitude in contraction pressure was found in the oviductal lumen, where it averaged $38 \mathrm{mmHg}$ (range $5-160 \mathrm{mmHg}$ ), and occasionally reached $200 \mathrm{mmHg}$. In the uterus, the mean amplitude was $20 \mathrm{mmHg}$ (range 3-70 $\mathrm{mmHg}$ ). The cervix usually showed small variations in luminal pressure, averaging $9 \mathrm{mmHg}$ (range $3-26 \mathrm{~mm} \mathrm{Hg}$ ). Cyclical changes in contraction amplitude occurred frequently in these organs at interval of $4-7$ days. Such a tendency was more distinct in the uterus and cervix than in the oviduct. It is suggested that motility in the reproductive tract of unmated rabbits is correlated with the ovarian cycle.
\end{abstract}

Jpn. J. Zootech. Sci., $52(5): 382-391,1981$

Our previous studies have shown that, under some conditions, eggs are expelled into the vagina of the rabbit within the time frame in which most investigators have assumed to include only oviductal egg transport; and that such eggs develop into normal young following embryo transfer by our technique ${ }^{1-4)}$. These results in our laboratory led us to investigate contractility in the reproductive tract of the rabbit in relation to egg transport.

Intraluminal pressure recordings as a measure of muscular activity have so far been performed mainly by use of balloon-ended, fluid-filled catheters. In this technique, the complete elimination of air bubbles has been regarded as essential. SALOMY and HAR$\mathrm{PER}^{5)}$ connected a second catheter to the recording catheter through a 27 -gauge needle to remove air bubbles, forming a closed flushing system. However, leakage of fluid from the recording system may have occurred, because a negative pressure frequently developed in their original polygraph recordings whenever oviductal activities became intense. SPILMAN and HARPER ${ }^{6)}$ removed air bubbles from the balloon portion by using a smaller second tube which was inserted through the lumen of the recording catheter 
and was slowly withdrawn, while flushing with physiological saline. AREF and HAFE 2,8) developed a dual, closed-end system consisting of two polyethylene catheters and one microballoon, but the double tube system seemed to be more cumbersome. Therefore, we tried to develop a new system for easy removal of air bubbles in the balloon part, and found that the problem could be solved by using a nylon plug to seal one end of the recording catheter.

Concerning the material of the balloon, we found that silicone tubing, which was used by SALOMY and HARPER $^{5)}$ and SpILman and HarPeR ${ }^{6}$, was difficult to fit to the catheter and was liable to burst in handling when making it thin. As for latex tubing, used by MAIA and Coutinio"), it is well known that the quality of the latex will change during long periods in vivo. In the present study, polyurethane was selected for the balloon, because polyurethane is easily handled and remains unchanged for long periods in vivo. Thus, our balloon catheter proved suitable for a chronic recording system.

We report here some fluctuations in the motility of the oviduct, uterus and cervix in the estrous rabbits, as a foundation for more advanced investigations.

\section{Materials and Methods}

\section{Preparation of Recording Catheter}

The modified balloon catheter used in the present study is illustrated in Fig. 1. The balloon part was made of polyurethane tubing (I.D. $1.4 \mathrm{~mm}$, O.D. $1.6 \mathrm{~mm}$ ) which was manufactured as follows: Cylindrical brazen casts of appropriate size were dipped ten times into $8 \%(\mathrm{~W} / \mathrm{W})$ polyurethane in tetrahydrofuran at $25-26^{\circ} \mathrm{C}$ and at less than $40 \%$ humidity. The polyurethane coating were dried at $50^{\circ} \mathrm{C}$ for ten hours. This polyurethane tubing was tied with $6-0$ silk thread at both ends, covering the fenestrated segment $(0.5 \times 1.0 \mathrm{~mm}, 3$ positions) of the polyethylene tubing (I. D. 0.7 $\mathrm{mm}$, O.D. $1.2 \mathrm{~mm}$ ). The thread was glued with adhesive agent and then coated with polyurethane solution. The sensitive part of the polyurethane balloon was $11 \mathrm{~mm}$ long. The recording catheter was flushed with physiological saline solution, with $70-100 \%$ ethanol used as an intermediate fluid. After complete removal of air bubbles from the catheter, the tip nearest the balloon was sealed with a nylon plug $(0.8 \mathrm{~mm}$ in diameter). The free end of the catherter, which was connected to a 20 -gauge needle,

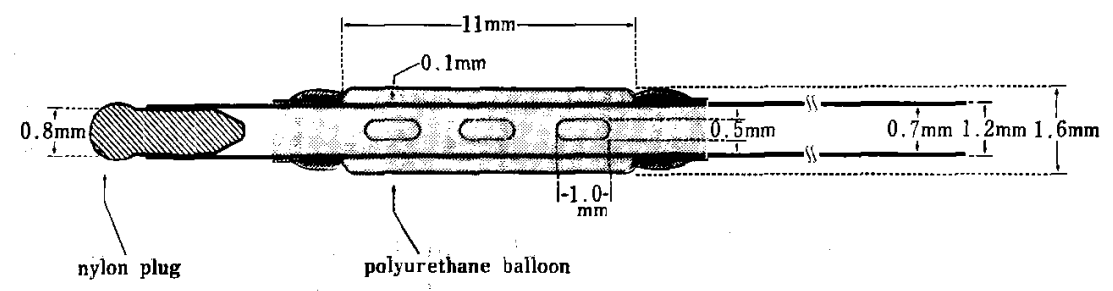

Fig. 1. Diagram of the pressure-recording balloon catheter. The fenestrated segment of the polyethylene catheter is covered with polyurethane tubing and the tip of the catheter is sealed with a nylon plug. 
was sealed with a plastic screw cap, also. Thus, the recording catheter was made the closed system.

To fix a catheter to the uterine muscle, three 6-0 silk threads were glued to the catheter at the rear of the balloon. For recording of oviductal or cervical pressure, $6-0$ or 0 surgical thread was glued to the tips of catheters.

\section{Calibration of Recording Catheter}

Prior to use, each recording catheter was tested for response to varying pressure (recorded from a mercury manometer) in a specially designed chamber in which pressure could be regulated by an air pump. Direct measurements from each recording catheter were recorded for increasing increments of added pressure. Then, a regression line was made for each recording catheter, and only catheters exhibiting similar linear responses were selected for simultaneous use in the oviduct, uterus and cervix.

\section{Surgical Procedure}

Nineteen adult female Japanese White rabbits in estrus, weighing $4-5 \mathrm{~kg}$, were used. The rabbits were anesthetized with sodium pentobarbital (Somnopentyl: PitmanMoore, Inc.) intravenously. The reproductive organs were exposed through an opening of the abdominal wall by midline incision and the ovaries were checked for nonovulation.

A thick polyethylene tube (I. D. $2.0 \mathrm{~mm}$, O.D. $3.0 \mathrm{~mm}, 40 \mathrm{~cm}$ in length), connected with a Kirschner's wire $(2.0 \mathrm{~mm}$ in diameter, $30 \mathrm{~cm}$ in length), was used to guide subcutaneously the recording catheter from the back of the neck to the abdominal cavity. In each rabbit, three catheters were led into the abdominal cavity the same way.

Before insertion of the catheter into the oviductal isthmus, a $50-\mathrm{mm}$ needle was inserted into the lumen of the isthmus through a small puncture made in the uterine horn within $1 \mathrm{~cm}$ of the uterotubal junction (UTJ). The needle was used to lead a catheter into the oviduct by pulling a 6-0 silk thread which was glued to the tip of the catheter. The catheter was then carefully worked through the UTJ to a position near the ampullary-isthmic junction, usually $5 \mathrm{~cm}$ from the UTJ, where the needle was pushed through the oviductal wall to the outside. The recording catheter, inserted into the isthmic portion, was fixed in position by attaching its tip to the oviductal wall by suturing it to a small silicone disc ( $3 \mathrm{~mm}$ in diameter) on the outside of the isthmus, and by suturing the 3 silk threads, which had been glued to the catheter at the rear of the balloon part, to the uterine muscle.

A second recording catheter was inserted into the uterine lumen through a small puncture of the uterine wall near the UTJ, just behind the puncture wound for the oviductal catheter. This catheter was placed in the central part of the uterine horn and fixed in position by ligation. A third one was introduced into the cervical lumen through a puncture wound in the uterine wall near the cervix, using large leading needle, $15 \mathrm{~cm}$ long. The tip of this catheter was ligated to the vaginal wall by the thread attached to the tip, and then the rear part of the balloon was ligated to the uterine wall. The free end of each catheter, closed by the plastic screw cap except at 
recording times, was concealed in a small plastic cabinet which was sutured to skin on the back of the neck. After closing the abdominal cavity, the animals were allowed to recuperate for 4 days before recordings were made.

\section{Experimental Procedure}

Daily recordings from each rabbit were performed for 1-2 hours, after securing the animal to a board in the supine position. For recordings of intraluminal pressure changes, the free end of each catheter was connected through a three-way stop-cock to a pressure transducer (MS 20-S, Ailtech, California) and multipurpose polygraph (RM-85, Nihon Kohden, Tokyo) with preamplifier (RPF-5, Nihon Kohden). By use of the three-way stop-cock, the resting pressure (the lowest pressure in consecutive contractions) was adjusted to atmospheric pressure. Pressure changes were registered by pen recorder and monitored simultaneously by a Braun's tube monitor (VC-85, Nihon Kohden). Inspection of each balloon catheter, after completion of recordings for 15 to 32 days, confirmed that the balloon part of the catheter still remained at the deposition site and that no air bubbles were present.

Although recording catheters were placed in the peritoneal cavity or the vaginal lumen in four animals, fluctuations of luminal pressure at these sites were found to be insignificant. Therefore, recordings in these locations were not made rountinely.

\section{Results}

The polyurethane tubing used in the present study was stable and durable for long periods of in vivo recording. In fact, good recordings were obtained even after half a year. As this tubing is transparent or semitransparent, air bubbles in the balloon part were easily recognizable and removable. The catheter design allowed repeated use with good results.

Representative recordings of the motility of the oviduct, uterus and cervix are shown in Figs. 2-5. Two patterns were recognized in the motility of the three dif-

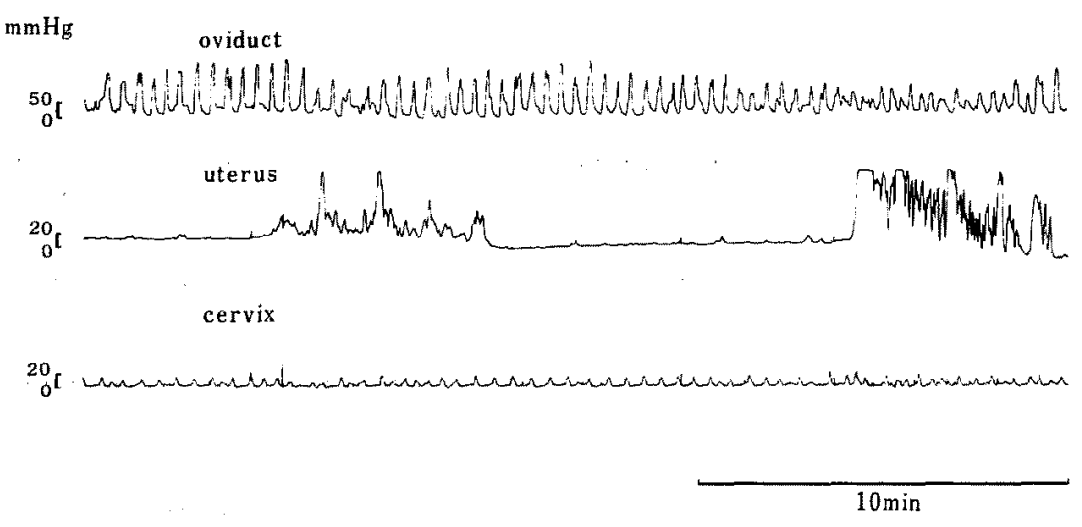

Fig. 2. Simultaneous recordings of contractile activities in the oviduct, uterus and cervix of rabbit no. 10 on Day 9 of recording. The lack of relationship between the outbursts of activity in the uterus and in the other two organs demonstrates independently spontaneous contractility in each organ. 


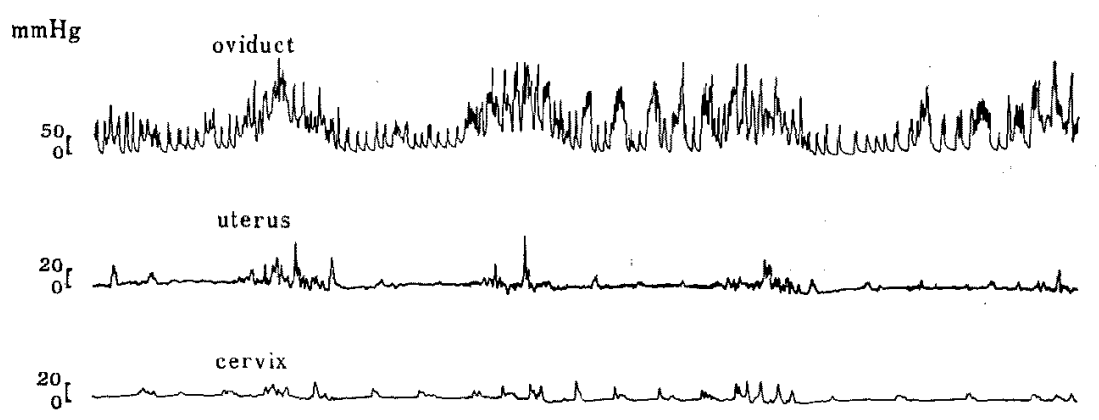

$10 \mathrm{~min}$

Fig. 3. Simultaneous recordings of contractile activities in the oviduct, uterus and cervix of rabbit no. 17 on Day 8 of recording. Synchronous outbursts among the three portions of the reproductive tract are noted.

ferent reproductive organs. In the first pattern, outbursts of increased activity, characterized by a sudden increase in tonus and in frequency of the contractions, appeared at varying intervals from 2 to $20 \mathrm{~min}$ (Figs. 2, 3). Synchronous correlation did not always exist among outbursts in the oviduct, uterus and cervix in the same animal (Fig. 2). In some cases, however, outbursts of contractions occurred simultaneously in these 3 organs (Fig. 3). There was no specific tendency in appearance of the outbursts in daily recordings.

The second pattern of motility consisted of rhythmic and relatively regular contractions, lasting the whole recording period without any appearance of outbursts (Figs. $4,5)$.

From the original polygraph recordings, the number and intensity of contractions were measured. In general, the frequency of contractions in each organ seemed to remain fairly constant from day to day, but there were daily variations in the amplitude of contractions in each organ.

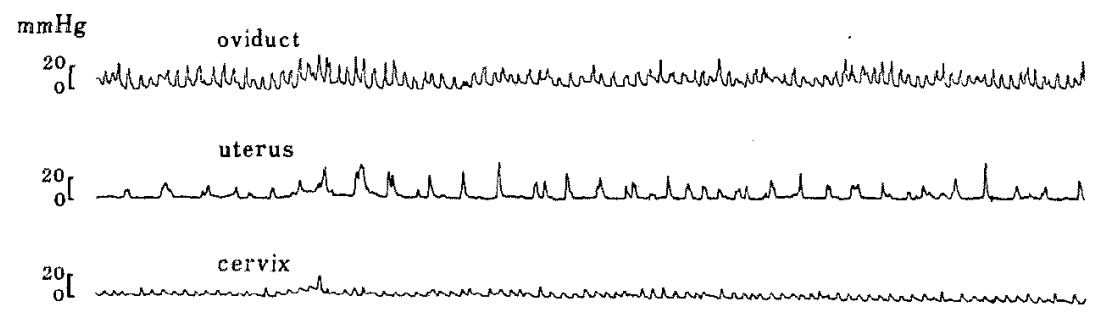

$10 \mathrm{~min}$

Fig. 4. Simultaneous recordings of oviductal, uterine and cervical contractile activities of rabbit no. 12 on Day 5 of recording. Synchronous, small increases in activity are noted in all organs at the left side of the recording, but the rythmic uterine and cervical contractions display relatively more stability in tonus than seen in the oviduct. 


\section{Oviductal, Uterine and Cervical Contraction Patterns}

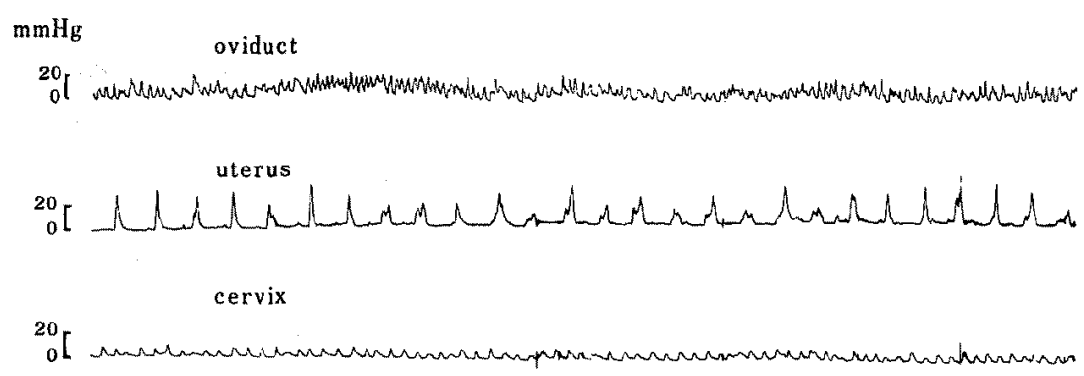

$10 \mathrm{~min}$

Fig. 5. Simultaneous recordings of contractile activities in the oviduct, uterus and cervix of rabbit no. 17 on Day 3 of recording. Uterine and cervical contractions are rythmic and regular, but oviductal contractions show a more variable pattern due to changes in frequency and tonus.

Oviductal motility was characterized by the highest frequency $(6.0 \pm 1.0 / \mathrm{min})$ and slight changes in tonus. The contraction amplitude in the oviduct $(38 \mathrm{mmHg}$ on the average) varied considerably, both among days and among individual animals. The amplitude ranged from 5 to $65 \mathrm{~mm} \mathrm{Hg}$ in 11 of 19 animals, but in other animals it frequently exceeded $100 \mathrm{mmHg}$ (5 to $160 \mathrm{mmHg}$ ) (Fig. 6), and in rare case reached $200 \mathrm{mmHg}$. The uterine contractions had a lower frequency $(1.0 \pm 0.3 / \mathrm{min})$, and a stable baseline was demonstrated in the recordings. The contraction amplitude in the uterus averaged $20 \mathrm{mmHg}$, ranging from $3-70 \mathrm{mmHg}$. In the cervix, the contraction frequency was higher than that of the uterus $(1.9 \pm 0.5 / \mathrm{min})$. The mean amplitude was $9 \mathrm{mmHg}$ and small variations among days and animals (range $3-26 \mathrm{mmHg}$ ) were

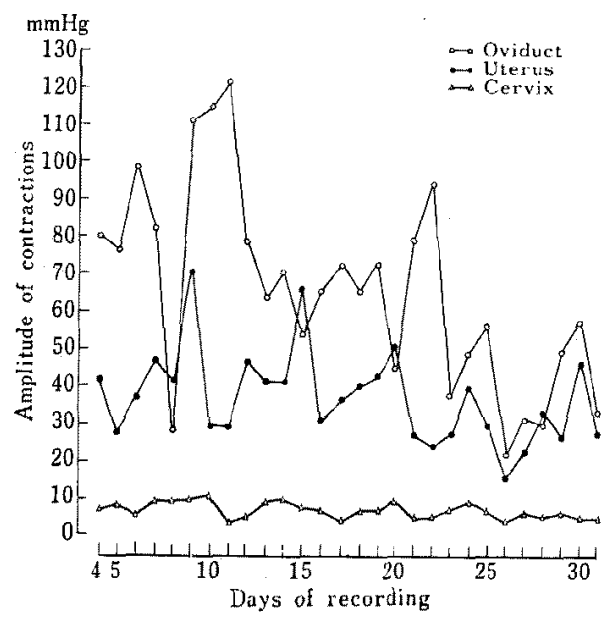

Fig. 6. Fluctuations of daily mean amplitudes of contractions in oviduct, uterus and cervix of rabbit no. 7 . Cyclical changes in contraction amplitude in the uterus and cervix occurred at intervals of 4-7 days, but such a tendency was less distinct in the oviduct due to considerable variation. 


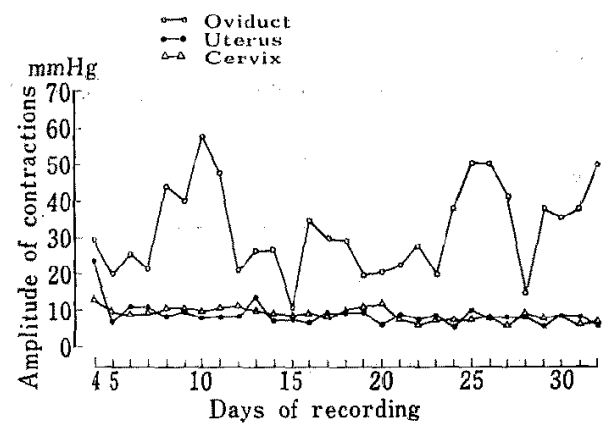

Fig. 7. Fluctuations of daily mean amplitude of contractions in oviduct, uterus and cervix of rabbit no. 11. There are cyclical changes in contraction amplitude only in the oviduct.

noted as a rule.

Daily recordings of intraluminal pressure in the uterus and cervix demonstrated, in almost all of the animals studied, that there were some cyclical fuctuations in each individual motility pattern (Figs. 6, 7), occurring every 4-7 days (5.6 days in average). With respect to oviduct motility, such a fluctuation pattern was not observed throughout the recording period, except for 4 animals in which cyclical changes of oviductal activity could be recognized during part of each recording period (Fig. 7).

\section{Discussion}

Recently, micro-transducers have been developed in recording intrauterine pressure in non-pregnant women ${ }^{10,11}$. With that technique, however, both the amplitude and the basal tonus in the recordings have been found to change sometimes, due to movement of the sensory surface of the catheter. The present recording system allows consistent recording of contractions based on maintenance of constant pressure by use of a three way stop-cock ( $i . e$., atmospheric pressure). MULLER and NELSEN ${ }^{13)}$ have recently pointed out that the presence of a foreign object within the oviductal lumen causes irritation, distension and interference with normal oviductal function; and for that reason they have proposed use of extraluminal transducers for measuring segmental contractile activity. However, such a technique can yield recordings of frequency only, and not amplitude of contraction. According to MAIA and CouTINHO ${ }^{13}$ and SALOMY and $\mathrm{HARPER}^{5)}$, possible mechanical interference by intraluminal catheters should be constant for all observations, and the effects of such a foreign body may be eliminated by a short period of adaptation before recordings are made.

With respect to daily variations in oviductal contractions, the amplitudes obtained in the present study are greatly different from some reported previously: $5-20 \mathrm{mmHg}^{14}$ ) and $1-25 \mathrm{mmHg}^{5}$. On the other hand, Fuchs ${ }^{15}$ ) has reported, for uterine motility, that the pattern of the activity varies considerably, ranging from strong rhythmic contractions to hardly any contraction at all; although the absolute values of intrauterine pressure are not given in her paper. However, quiescent periods between bursts of uterine activity in non-pregnant rabbits ${ }^{15)}$, as well as those described in the oviduct 
by SALOMY and HarPeR ${ }^{5}$, were not noted in the present study. This is presumably due to the capacity of the pressure transducer used in the present investigation, rather than the sensitivity of the recording catheter. According to the specifications given by Ailtech, the transducer we used has a high natural frequency and very low volumetric displacement $\left(6 \times 10^{-6} \mathrm{~mm}^{5} / \mathrm{mm} \mathrm{Hg}\right)$, and this may result in high sensitivity in the recording system.

As far as we know, no report has been published on recordings of cervical activity in the rabbit. In vivo and in vitro studies in women revealed that the cervix is capable to developing spontaneous contractility independent of that of the uterus ${ }^{16-20)}$. The present study indicates that spontaneous motility of smaller amplitude occurs in the rabbit cervix, also. The smaller amplitude may result from structural characteristics of the cervix, which is composed of scanty muscular tissue ${ }^{21}$.

Matros and Coutinho ${ }^{14)}$ reported that no consistent change in the pattern of tubal activity was observed in rabbits, except for some variation in the frequency of outbursts. However, SALOMY and $\mathrm{HARPER}^{5}$ ) observed cyclical peaks of tubal activity, occurring every 4-7 days. Although some periodicity was demonstrated occasionally in the contractile activities of the oviduct in the present study, more distinct cyclical changes occurred in the motilities of the uterus and cervix. Thus, it may be asserted that there is a cyclical fluctuation in contractility of the reproductive tract during the nonovulating phase.

It is well known that the rabbit have no definite estrous cycle comparable to that of spontaneous ovulators. However, there were several reports documenting some sexual cycle in the unmated female rabbit. Cyclical changes, at 4-to-6-day intervals, occur in the vaginal smear and histology of the reproductive tract, especially the endometrium ${ }^{22,23)}$. When female rabbits are running with vasectomized males, the does periodically becomes sexually attractive to the males at intervals of 4-6 days, or multiples thereof ${ }^{24)}$. According to NALBANDov ${ }^{25)}$, in rabbits a period of sexual receptivity of two or three days is followed by an anestrous period of approximately equal duration, corresponding to the growth and atresia of follicles. HAMILTON ${ }^{22)}$ also indicated possible variations in estrogen output, which was at a peak during a certain phase of the vaginal-smear cycle. TsuTsumi and MATsumoto ${ }^{26,27}$ ) have reported that the female rabbit exhibits cyclical fluctuations in levels of free vaginal epithelial cells (about 5.6 days, average interval), in the crystal pattern of dried vaginal flushings (5.7 days), and in vaginal $\mathrm{pH}$ (5.6 days). These cyclical fluctuations were correlated with the appearance of large follicles in the ovary ${ }^{27}$. Similar cyclical fluctuations in female rabbits have been shown in body temperature (5.6 days) ${ }^{28)}$, red-blood-cell count (5.5 days $)^{29)}$ and leucocyte count $(5.8 \text { days })^{30)}$. Therefore, it is not surprising that cyclical fluctuations in intraluminal reproductive tract pressure have been found to exhibit similar intervals (5.6 days). Cyclical fluctuations in estrogen output by the ovaries may explain cyclical variations in motility of the reproductive organs, because both oviductal and uterine activities are increased considerably after ovariectomy and are depressed by estrogen treatment, in spite of an increase in the occurrence of outbursts 
and frequency of the contractions ${ }^{14,15,81)}$.

\section{Acknowledgement}

The authors wish to express their sincere thanks to Prof. W. J. Mellen, Department of Veterinary and Animal Sciences, University of Massachusetts, Amherst, U.S.A., for reading the manuscript and offering his valuable suggestions.

\section{References}

1) Tsutsumi, Y., T. Takeda, K. Yamamoto and Y. Tanabe, J. Reprod, Fert., 48: 393-395. 1976.

2) Tsutsumi, Y., Y. Terami, T. Takeda, H. Suzuki and S. Matsul, Japan. J. Anim. Reprod, 26: 6-14. 1980.

3) Takeda, T., Y. Tsutsumi, S. Hara and M. Ida, Fert. Steril., 30: 79-85. 1978.

4) Taked., T, H. Suzumi, Y. Terami and Y. Tsutsumi, Japan. J. Anim. Reprod., 25: $23-30$. 1979.

5) Salomy, M. and M. J. K. Harper, Biol. Reprod., 4: 185-194. 1971.

6) Spllman, C. H. and M. J. K. Harper, Biol. Reprod., 9: 36-45. 1973.

7) Aref, I. and E. S. E. Hafez, Obstet. Gyn. Survey, 28:679-703. 1973.

8) Aref, I. and E. S. E. Hafe 7, Obstet. Gyn., 42: 165-171. 1973.

9) Maia, H. and E. M. Coutinho, Am. J. Obstet. Gyn., 102: 1043-1047. 1968.

10) Äkerlund, M., L. Ph. Bengtsson and U. Ulmsten, Acta Obstet. Gyn. Scand., 57: 427-433. 1978 .

11) Ulmsten, U. and K. E. Andersson, Acta Obstet. Gyn. Scand,, 58: 115-120. 1979.

12) Muller, H.H, and T.S. Nelsen, Biol. Reprod., 21: 563-574. 1979.

13) Maia, H. and E. M. Coutinho, Biol. Reprod., 2: 305-314. 1970.

14) Matros, C. E. R. and E. M. Coutinho, Endocrinology, 89: 912-917. 1971.

15) Fuchs, A. R., Fert. Steril., 23: 915-923. 1972.

16) Danforth, D. N., Am. J. Obstet. Gyn., 68: 1261-1271. 1954.

17) Hughesden, P. E., J. Obstet. Gyn. Br. Emp., 59: 763-776. 1952.

18) Schild, H.O., R. J. Fitzpatrick and W. C. W. Nixon, Lancet, 1: 250-253. 1951.

19) Hillier, K. and S. M. M. Karim, Br. J. Pharmacol., 40: 576-577. 1970.

20) Coutinho, E. M. and E. Darzé, Am. J. Obstet. Gyn., 126: 224-225. 1976.

21) Suzuki, H., T. Takena and Y. Tsutsumi, Jpn. J. Zootech. Sci., 49: 614-624. 1978.

22) Hamilton, C. E., Anat. Rec., 110: 557-571. 1951.

23) Tsursumi, Y., J. Fac. Agr. Hokkaido Univ., 54: 151-185. 1965.

24) Myers, K. and W. E. Poole, Nature, Lond., 195: 358-359. 1962.

25) Nalbandov, A. V., in Reproductive Physiology of Mammals and Birds. (Nalbandoy, A. V., eds.) 3rd ed. 157-180. W. H. Freenan and Co., San Francisco. 1976.

26) Tsutsumi, Y. and K. Matsumoto, Memoirs Fac. Agr. Hokkaido Univ., 2: 181-194. 1956.

27) Tsursumi, Y. and K. Matsumoto, Memoirs Fac. Agr. Hokkaido Univ., 3: 185-199. 1959.

28) Tsursumi, Y., M. Takahashi, N. Oguri and Y. Hachinohe, J. Fac. Agr. Hokkaido Univ, 55: 363-381. 1968.

29) Tsutsumr, Y., M. Takahashi, N. Oguri and Y. Hachinohe, J. Fac. Agr. Hoklsaido Univ., 55: 402-420. 1968.

30) Tsutsumi, Y., M. Takahashi, N. Oguri and Y. Hachinohe, J. Fac. Agr. Hokkaido Univ., 56: 103-116. 1969.

31) Couninho, E. M. and C. E. R. M^tтos, Endocrinology, 83: 422-432. 1968. 


\title{
未交配家鬼卵管，子宮ならびに子宮頙内正の同時测定
}

\author{
鈴木裕之・堤義雄・小川桂屹* \\ 北酒道大学㥳学部，忙愰市 060 \\ *日本光需工策(㧣) 新宿区 161
}

ナイロン栓で密栓した新型ポリウレタン・バルーンカ テールを用いて，未交配家重の卵管，子宮ならびに子宫 頸の内压变化龙測定した。卵管の収維頻度 $(6.0 \pm 1.0$ / 分）屿，子宮 $(1.0 \pm 0.2 /$ 分 $)$ と子宮頸 $(1.9 \pm 0.5 /$ 分 $)$ よりも高かった．突発性收縮が反復して諗められたが， 生殖器各部位でかならずしも同調していなかった１日 1-2 時間の測定を 15-32 日間続けた結果, それぞれの 器管の収縮振輻には日变動がみられた３部位中卵管の 内压が最も高く(平均， $38 \mathrm{mmHg}$ )，加つ変動も著しか
った(籁罒，5-160 $\mathrm{mm} \mathrm{Hg}$ ). 子宫の平妁振幅は 20

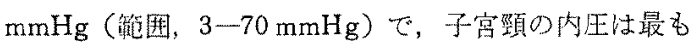
変動が小さ平均 $9 \mathrm{mmHg}$ (籁围 $3-26 \mathrm{mmHg}$ )であっ た. 各器管の収繀要動の振幅化はしばしば 4-7日(平 均，5.6日）間隔の周期的变化が みられた。 その傾向は 卵管よりも子宮と子宮頸で明瞭に認められた，未交配家 鬼生殖器道の運動性は卵巣周期と閔連していることが示 唆された。

日畜会報，52(5)：382-391，1981 